\title{
Compliance Cap
}

National Cancer Institute

\section{Source}

National Cancer Institute. Compliance Cap. NCI Thesaurus. Code C78752.

A cap for a medication that contains a memory device designed to indicate if the medication has been taken. 